Gut, 1978, 19, 759-764

\title{
Effect of colchicine and vinblastine on rat intestinal water transport and Na-K-ATPase activity
}

\author{
D. RACHMILEWITZ1, R. FOGEL, AND F. KARMELI \\ From the Gastroenterology Service, Hadassah University Hospital, Jerusalem, Israel
}

SUMMARY The hypothesis that colchicine and vinblastine, which are commonly used for therapeutic purposes and known to cause diarrhoea, decrease intestinal water transport by inhibition of Na-KATPase activity was tested in rats. Net fluid transport by jejunal segments was measured four hours after intraperitoneal injection of either $0.15 \mathrm{M} \mathrm{NaCl}(0.5 \mathrm{ml} / 100 \mathrm{~g})$, colchicine $(0.5 \mathrm{mg} / 100 \mathrm{~g} \mathrm{~b} . w$.$) ,$ or vinblastine $(1.0 \mathrm{mg} / 100 \mathrm{~g} \mathrm{b.w.)}$. Colchicine and vinblastine decreased net fluid transport: $3.0 \pm 0.9$ (SE) and $4.6 \pm 0.4(\mathrm{SE})$ respectively, as compared to that transported by segments from rats injected with $0.15 \mathrm{M} \mathrm{NaCl}, 8.6 \pm 0.7$ (SE) g fluid/hour/g. Methylprednisolone (3.0 mg/100 g b.w.) abolished the inhibitory effect of cholchicine and vinblastine on fluid transport. Colchicine and vinblastine were found to decrease significantly mucosal Na-K-ATPase activity, $18.2 \pm 4.9$ (SE); $25.2 \pm 2.4$ (SE) respectively, as compared to that measured in rats injected with saline $40.6 \pm 3.4$ (SE) $\mu \mathrm{mol} /$ $\mathrm{mg}$ protein/hour. Pretreatment with methylprednisolone prevented the decrease in enzyme activity observed in rats injected with colchicine and vinblastine. The degree of inhibition in intestinal Na-K-ATPase activity was similar to that observed in fluid transport following colchicine and vinblastine. It is thus suggested that colchicine-induced inhibition of water transport is caused by inhibition of Na-K-ATPase activity, an effect which can be prevented by pretreatment with methylprednisolone.

Colchicine is used for the treatment of acute gout and lately also commonly used to prevent acute attacks of familial Mediterranean fever (Zemer et al., 1974). Diarrhoea is a frequent side-effect of colchicine therapy, but the mechanism of this has not been elucidated. Colchicine was found to depress intestinal disaccharidase activities in man (Herbst et al., 1970) and guinea-pig (Cohen and McNamara, 1970) and to inhibit intestinal mucosal dehydrogenase in mice (Myren et al., 1966). Colchicine and vinblastine have been reported to decrease also lipoprotein lipase activity by $50 \%$ in rats (Chajek et al., 1975).

We tested the hypothesis that colchicine and vinblastine, two microtubular disrupting agents (Olmstead and Borisy, 1973), inhibit water transport from the rat small intestine by inhibiting Na-KATPase activity, an enzyme which plays an important role in the intestinal absorption of sodium and water under basal conditions (Charney and Donowitz, 1977).

\footnotetext{
${ }^{1}$ Address for correspondence: Dr D. Rachmilewitz, Division of Gastroenterology, Hadassah University Hospital, P.O. Box 499, Jerusalem, Israel.

Received for publication 2 March 1978
}

\section{Methods}

ANIMALS

Non-fasted male rats (200-400 g) of Hebrew University strain were studied under the following experimental conditions: one group of rats was injected intraperitoneally with $0.15 \mathrm{M} \mathrm{NaCl}(0.5 \mathrm{ml} /$ $100 \mathrm{~g}$ body weight). A second group of rats was injected intraperitoneally with either colchicine, $0 \cdot 5$ $\mathrm{mg} / 100 \mathrm{~g}$ body wt (Sigma Chemical Co., St. Louis, Mo.), or vinblastine, $1 \mathrm{mg} / 100 \mathrm{~g}$ body wt (Eli Lilly Co., Indianapolis, Ind.) dissolved freshly in $0.15 \mathrm{M}$ $\mathrm{NaCl}$. In a third group of rats a single subcutaneous injection of methyl prednisolone, $3.0 \mathrm{mg} / 100 \mathrm{~g}$ body weight (Upjohn, Belgium) was given 30 minutes before the intraperitoneal injection of either $0.15 \mathrm{M}$ $\mathrm{NaCl}$, colchicine, or vinblastine.

One, two, and four hours after the intraperitoneal injection of colchicine and four hours after the intraperitoneal injection of $0.15 \mathrm{M} \mathrm{NaCl}$ or vinblastine jejunal segments were taken for either infusion or Na-K-ATPase activity studies. The enzymatic assay was carried out immediately after killing the animals. 
EXPERIMENTAL PROCEDURE

Infusion studies

Rats were anaesthetised with ether and a jejunal segment (10-15 cm long) $3 \mathrm{~cm}$ distal to the ligament of Treitz was separated. The segment was cannulated at both ends and flushed with $30.0 \mathrm{ml}$ of a buffer solution containing $115 \mathrm{mM} \mathrm{NaCl}, 6 \mathrm{mM} \mathrm{KCl}, 10$ $\mathrm{mM} \mathrm{NaHCO}, 1.0 \mathrm{mM} \mathrm{CaCl}$, and $28 \mathrm{mM}$ glucose. While the mesentery was still intact, the segment was connected to a reservoir and infused through the lumen of the intestinal segment with $50 \mathrm{ml}$ of the above-mentioned buffer by means of a gas $(95 \%$ $\mathrm{O}_{2}-5 \% \mathrm{CO}_{2}$ ) lift. The buffer recirculated at a rate of about $25 \mathrm{ml} / \mathrm{min}$. The mesentery was cut, the serosal surface of the segment was washed with buffer, and the segment was then placed in a mineral oil bath. The temperature of the bath and reservoir were kept at $37^{\circ} \mathrm{C}$ and the hydrostatic pressure in the segment was $18 \mathrm{~mm} \mathrm{Hg}$ (gas phase $95 \% \mathrm{O}_{2}+5 \% \mathrm{CO}_{2}$ ). The transported fluid from the infused segment appeared as droplets of 'sweat' on the serosal surface, accumulated at the bottom of the mineral oil bath and collected through a stopcock. The transported fluid from the first 30 minutes of the infusion was discarded, whereas that from the second 30 minutes' interval was weighed and analysed for sodium and potassium concentration (flame photometer 343, Instrumentation Laboratory Inc.). The intestinal segment was washed in petroleum ether and dried at $100^{\circ} \mathrm{C}$ for 24 hours before weighing. To check for the presence of leaks from the infused segment, 2 $\mu \mathrm{Ci}$ polyethylene-(1,2-3 $\mathrm{H}$ )glycol (New England Nuclear Corporation. Boston, Mass.) were added to the infusate in each experiment. Experiments in which the ratio of ${ }^{3} \mathrm{H}$ in the transported fluid to that of the infusate was greater than $5 \cdot 10^{-3}$ were discarded.

ENZYME ASSAYS

The small intestine was removed under light ether anaesthesia and flushed with cold $0.15 \mathrm{M} \mathrm{NaCl}$ containing $5 \mathrm{mM} \mathrm{Na}$ EDTA. The intestine was opened on a filter paper and the mucosa scraped with a scalpel and homogenised with a Teflon pestle and iced glass homogeniser with 19 volumes of ice cold buffer containing $130 \mathrm{mM} \mathrm{NaCl}, 5 \mathrm{mM} \mathrm{Na} 2 \mathrm{EDTA}$, $30 \mathrm{mM}$ imidazole, and $2.4 \mathrm{mM}$ sodium deoxycholate. After centrifugation at $700 \mathrm{~g}$ for 10 minutes at $0^{\circ} \mathrm{C}$, the supernatant was filtered through a double layer of gauze and then centrifuged at $10000 \mathrm{~g}$ for 10 minutes at $0^{\circ} \mathrm{C}$. The pellets obtained were resuspended in a solution containing $130 \mathrm{mM} \mathrm{NaCl}, 5 \mathrm{mM}$ $\mathrm{Na}_{2}$ EDTA and $30 \mathrm{mM}$ imidazole. The amount of solution added equalled the initial weight of mucosa taken for homogenisation $(1: 1, w / v)$ (Quigley and Gotterer, 1969; Charney et al., 1974). Protein concentration was determined (Lowry et al., 1951).
The resuspended pellets were assayed for $\mathrm{Na}-\mathrm{K}$ ATPase activity (Quigley and Gotterer, 1969; Charney et al., 1974; 1975). Triplicate samples of the $10000 \mathrm{~g}$ pellets were incubated in a medium containing $100 \mathrm{mM} \mathrm{NaCl}, 20 \mathrm{mM} \mathrm{KCl}, 10 \mathrm{mM}$ imidazole, $5.4 \mathrm{mM} \mathrm{MgCl}_{2}$, and $5.4 \mathrm{mM}$ ATP (disodium salt, Sigma Chemical Co., Grade II) and in a medium from which the $\mathrm{KCl}$ was omitted and the $\mathrm{NaCl}$ concentration was $120 \mathrm{mM}$. The final incubation volume of $5 \mathrm{ml}$ contained $100-400 \mu \mathrm{g}$ protein. The incubation was carried out at $37^{\circ} \mathrm{C}$ for 15 minutes and terminated by the addition of $1 \mathrm{ml} \mathrm{TCA} 35 \%$. Blanks containing no enzyme were run with each incubation. The samples were centrifuged and the inorganic phosphate liberated was measured (Fiske and SubbaRow, 1925). Na-K-ATPase activity was defined as the difference between inorganic phosphate released in the presence and absence of potassium in the incubation mixture. Mg-ATPase was defined as the amount of inorganic phosphate released in the absence of potassium from the incubation mixture. The results are expressed as $\mu$ moles inorganic phosphate liberated per $\mathrm{mg}$ protein per hour. Statistical evaluation of the data is based on Student's $t$ test for unpaired data.

\section{HISTOLOGICAL TECHNIQUES}

Four hours after the intraperitoneal injection of 0.15 $\mathrm{M} \mathrm{NaCl}$, colchicine, or vinblastine, a $1-\mathrm{cm}$ long section was removed from the jejunum and placed on a stiff piece of paper. The section was opened with scissors and was placed in Bouin's fixative. The fixed specimen was trimmed, dehydrated in ethanol, embedded in paraffin, serially sectioned at 4-5 microns and stained with haematoxylin and eosin.

\section{Results}

Colchicine and vinblastine decreased the amount of fluid transported by jejunal segments as compared to that transported by segments of rats injected with $0.15 \mathrm{M} \mathrm{NaCl} 3.0 \pm 0.9$ (SE), $4.6 \pm 0.4$ (SE), and $8 \cdot 6 \pm 0 \cdot 7$ (SE) $\mathrm{g}$ fluid/hour/g respectively (Table 1). Concomitant with the decrease in the fluid transport, colchicine and vinblastine treatment resulted in a decrease in sodium and potassium quantity in the transported fluid (Table 2).

Methylprednisolone, injected subcutaneously in a single dose of $3.0 \mathrm{mg} / 100 \mathrm{~g}$ b.w., 30 minutes before the intraperitoneal injection of either colchicine or vinblastine, prevented the inhibitory effect of colchicine and vinblastine on fluid transport. The amount of fluid transported did not differ significantly from that transported by segments of rats injected with $0.15 \mathrm{M} \mathrm{NaCl}$ or methylprednisolone alone (Table 1). 
Table 1 Effect of colchicine, vinblastine, and methylprednisolone on intestinal water transport *

\begin{tabular}{llc}
\hline Treatment & Number of rats & $\begin{array}{l}\text { Water transport } \\
\text { (g fluid/hour/g } \\
\text { dry tissue) }\end{array}$ \\
\hline $0.15 \mathrm{M} \mathrm{NaCl}$ & 9 & $8.6 \pm 0.7^{\mathrm{a}} \dagger \ldots$ \\
Colchicine & 7 & $3.0 \pm 0.9^{\mathrm{b}}$ \\
Vinblastine & 8 & $4.6 \pm 0.4^{\mathrm{c}}$ \\
Methylprednisolone & 6 & $10.1 \pm 0.6$ \\
Colchicine + methylprednisolone & 7 & $7.5 \pm 0.9^{\mathrm{d}}$ \\
Vinblastine + methylprednisolone 8 & $7 \cdot 3 \pm 0.5^{\circ}$ \\
\hline
\end{tabular}

-Rats were injected intraperitoneally with either $0.15 \mathrm{M} \mathrm{NaCl} 0.5 \mathrm{ml} /$ $100 \mathrm{~g}$ body wt, colchicine $0.5 \mathrm{mg} / 100 \mathrm{~g}$ body wt, vinblastine $1.0 \mathrm{mg} / 100$ g body wt, or subcutaneously methylprednisolone $3.0 \mathrm{mg} / 100 \mathrm{~g}$ body wt. In some experiments methylprednisolone was injected 30 minutes before the colchicine or vinblastine. Infusions of jejunal segments with buffer were performed as described in the Methods section. Values are means \pm SE.

ta vs. $\mathrm{b} P<0.01$; a vs. c $\mathrm{P}<0.01$; b vs. $\mathrm{d} P<0.01$; c vs. e $\mathrm{P}<0.01$.

Table 2 Effect of colchicine, vinblastine, and methylprednisolone on electrolyte quantity of transported fluid*

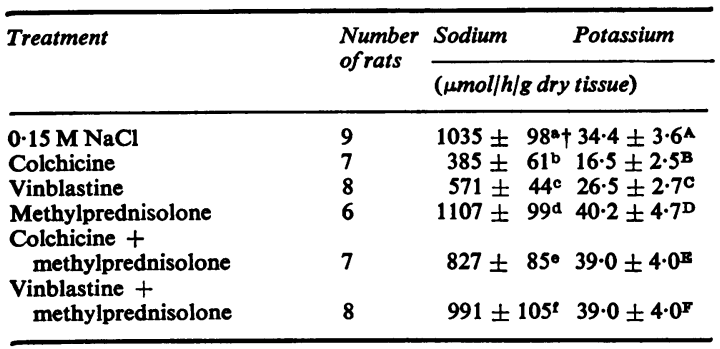

*As in Table 1.

Infusion of jejunal segments with buffer and measurement of $\mathrm{Na}$ and $K$ content in transported fluid were performed as described in the Methods section. Values are means $\pm \mathrm{SE}$.

ta vs. b P $<0.01$; a vs. c $P<0.01$; b vs. e $P<0.01$; c vs. $f P<0.01$. A vs $B$ P $<0.01$; A vs. C NS; B vs. E $P<0.01 ;$ C vs. F $P<0.05$. $(\mu \mathrm{mol}=\mu$ equiv. $)$

Intestinal Mg-ATPase and Na-K-ATPase activities were measured four hours after the intraperitoneal injection of either $0.15 \mathrm{M} \mathrm{NaCl}$, colchicine $0.5 \mathrm{mg} / 100 \mathrm{~g}$ b.w. or vinblastine $1.0 \mathrm{mg} / 100 \mathrm{~g}$ b.w. in rats treated and not treated with methylprednisolone. The results obtained in these series of experiments are summarised in Table 3. Mg-ATPase activity was similar in the groups injected with $0.15 \mathrm{M} \mathrm{NaCl}$, colchicine, methylprednisolone, and methylprednisolone plus colchicine. Mg-ATPase activity in the vinblastine injected group was lower than that in the other groups. Intestinal Na-K-ATPase activity was markedly decreased in rats injected with either colchicine or vinblastine as compared to rats injected with $0.15 \mathrm{M} \mathrm{NaCl}$. Methylprednisolone stimulated significantly Na-K-ATPase activity as compared to that observed in $0.15 \mathrm{M} \mathrm{NaCl}$ treated rats. The same magnitude of inhibition in Na-K-ATPase activity
Table 3 Effect of colchicine, vinblastine, and methylprednisolone on intestinal $N a-K-A T P a s e$ and $M g-A T P a s e$ activities*

\begin{tabular}{|c|c|c|}
\hline \multirow[t]{2}{*}{ Treatment } & \multirow[t]{2}{*}{$\begin{array}{l}\text { Number } \\
\text { of rats }\end{array}$} & $\begin{array}{l}\text { Na-K-ATPase } M g-A T P a s e \\
\text { activity activity }\end{array}$ \\
\hline & & ( $\mu \mathrm{mol} / \mathrm{mg}$ protein/hour) \\
\hline $\begin{array}{l}0 \cdot 15 \mathrm{M} \mathrm{NaCl} \\
\text { Colchicine } \\
\text { Vinblastine } \\
\text { Methylprednisolone } \\
\text { Colchicine + } \\
\text { methylprednisolone } \\
\text { Vinblastine + } \\
\text { methylprednisolone }\end{array}$ & $\begin{array}{r}11 \\
8 \\
9 \\
6 \\
\\
10\end{array}$ & $\begin{array}{l}40.6 \pm 3.4^{\mathrm{a}}+43.1 \pm 5.5 \\
18.2 \pm 4.9^{\mathrm{b}} 35.7 \pm 5.9 \\
25.2 \pm 2.4^{\mathrm{c}} 22.8 \pm 1.5 \\
71.0 \pm 11.8^{d} 46.8 \pm 7.8 \\
42.9 \pm 5.3^{\circ} 39.7 \pm 4.6 \\
32.3 \pm 1.8^{\mathrm{s}} 34.8 \pm 1.9\end{array}$ \\
\hline
\end{tabular}

*As in Table 1.

Na-K-ATPase and Mg-ATPase activities of jejunal mucosa were determined as described in the Methods sections. Values are means \pm SE.

ta vs. b $P<0.01$; a vs. c $P<0.01$; a vs. $d P<0.02$; b vs. e $P<0.01$; c vs. $f P<0.05$.

was induced by colchicine and vinblastine both in the $0 \cdot 15 \mathrm{M} \mathrm{NaCl}$ and methylprednisolone treated rats. Pretreatment with methylprednisolone prevented the decrease in intestinal Na-K-ATPase activity observed following colchicine or vinblastine. Addition of 30 and $60 \mu \mathrm{g}$ colchicine or of 60 and $120 \mu \mathrm{g}$ vinblastine to $5.0 \mathrm{mg}$ of the assay medium did not interfere with the detection of both enzymes' activities.

The degree of inhibition in intestinal Na-K-ATPase activity was similar to the decrease observed in fluid transport following colchicine and vinblastine. The reversal effect of methylprednisolone on enzyme activity and fluid transport was also of the same magnitude (Fig. 1). In order to check whether the effects of colchicine on fluid transport and enzyme activities can be separated, both were measured one and two hours after the administration of the drug. As can be seen in Fig. 2, one and two hours after its administration, colchicine decreased fluid transport and inhibited Na-K-ATPase significantly as compared to rats injected with $0.15 \mathrm{M} \mathrm{NaCl}(\mathrm{P}<0.01)$. The degree of inhibition in the enzyme activity was similar to the decrease in fluid transport at both time intervals.

Histologically, it was impossible to distinguish between jejunums from rats treated with colchicine or with methylprednisolone and colchicine. In both groups the jejunal surface absorptive cells were tall columnar, had basally oriented nuclei and a normal appearing brush border. In the crypts of both groups mitotic arrest in metaphase was observed. In the groups injected with vinblastine or methylprednisolone plus vinblastine besides mitotic arrest in metaphase, other changes were observed: vacuolisation, focal disarray of nuclei, accumulation of nuclear debris, and disappearance of the brush bor- 

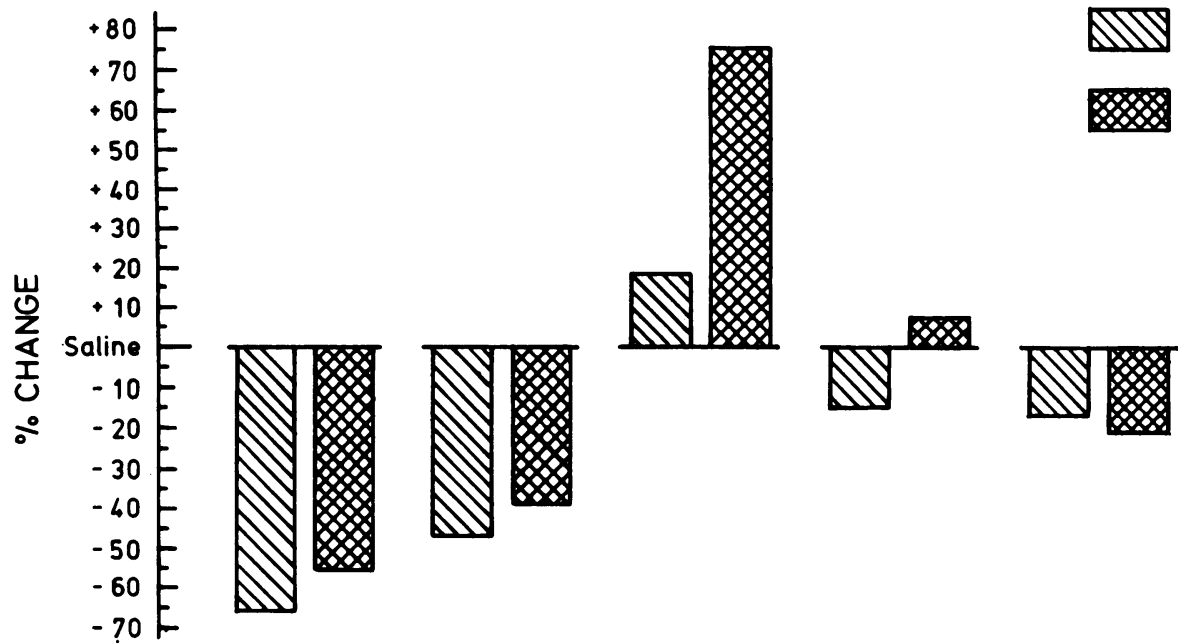

COLCHICINE

VINBLASTINE

METHYL
PREDNISOLONE

METHYL METHYL

PREDNISOLONE PREDNISOLONE

COLCHICINE VINBLASTINE

Fig. 1 Percent changes in fluid transport and Na-K-ATPase activity in jejunal segments from rats treated with colchicine, vinblastine, and methylprednisolone as compared to segments from rats injected with $0 \cdot 15 \mathrm{M} \mathrm{NaCl}$.

SALINE

FLUID

TRANSPORT

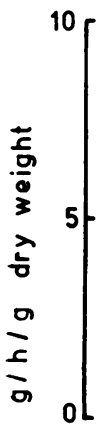

1 HOUR

2 HOURS

4 HOURS

$\mathrm{Na}^{+} \mathrm{K}^{+}$ATP ase

COLCHICINE

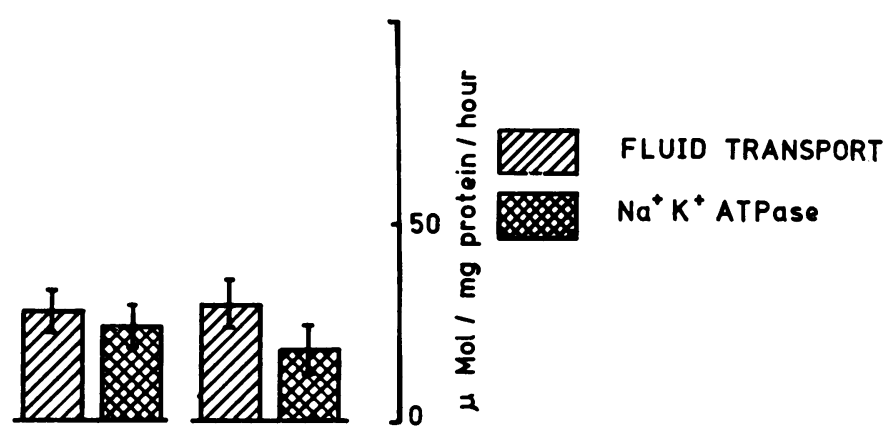

Fig. 2 Fluid transport and Na-K-ATPase activity one, two, and four hours after the intraperitoneal injection of colchicine, $0.5 \mathrm{mg} / 100 \mathrm{~g}$ b.w. Results are mean $\pm S E$ of groups of five to 10 rats.

der were noted among the superficial absorptive cells.

\section{Discussion}

The in vitro intestinal infusion system (Parsons and Volman-Mitchell, 1974) allows easy collection of transported fluid at the serosal surface of the infused intestinal segment. This system was used in order to study the effects of colchicine and vinblastine on water transport by the rat's jejunum. It is impossible to differentiate in this system whether the inhibition of fluid transport is the result of decreased absorption or increased secretion. However, the results obtained illustrate that both colchicine and vinblastine in the doses used decreased significantly 
the transport of fluid by the rat's jejunum.

Pretreatment with methylprednisolone prevented the inhibitory effect of colchicine on water transport. This observation might be explained on the basis of the data showing that methylprednisolone increases sodium and water absorption, potassium secretion, and $\mathrm{Na}^{+}-\mathrm{K}^{+}$-ATPase activity in the jejunum of rats (Charney et al., 1975). Even though adenylate cyclase is the mediator in choleragen-induced intestinal secretion, it has also been shown that methylprednisolone may prevent and reverse the secretory effects of choleragen by increasing mucosal Na-KATPase activity (Charney and Donowitz, 1976).

In the present study we confirmed again that methylprednisolone increases intestinal $\mathrm{Na}-\mathrm{K}$ ATPase activity. Moreover, methylprednisolone was shown to prevent the decrease in the enzyme activity observed following the administration of colchicine and vinblastine.

Our results thus suggest, that inhibition of Na-KATPase activity by colchicine and vinblastine, in addition to their effects on intestinal morphology and other enzyme activities, might contribute to the inhibition of water transport from the rat intestine induced by them.

Colchicine, in the dose injected, was already effective one hour after its administration. At all time intervals studied, it was impossible to differentiate between colchicine's effect on water transport and $\mathrm{Na}^{+}-\mathrm{K}^{+}-$ATPase activity. This further supports the contention that its inhibition of water transport is related to the inhibition of $\mathrm{Na}^{+}-\mathrm{K}^{+}-\mathrm{ATPase}$ activity.

Colchicine in the dose range used does not interfere in protein synthesis (Rossignol et al., 1972) and thus the lower Na-K-ATPase activity is not due to inhibition of the enzyme synthesis. Colchicine has been shown to effect' release of various hormones (Lacy et al., 1968; Williams and Wolff, 1970; Douglas and Sorimachi, 1972) into the circulation, it could thus affect the transport of Na-K-ATPase from its storage site. Another possibility to be considered is that colchicine might interfere with the final step of enzyme release if it is transported to its location on the lateral membrane fraction of the cell (Quigley and Gotterer, 1969) in plasmalemmal vesicles. Colchicine has recently been shown to bind to cellular membranes (Stadler and Franke, 1974) and by this can prevent the fusion of the enzyme carrying plasmalemmal vesicles with the plasma membrane and thus to reduce the amount of available enzymes.

Methylprednisolone prevents less effectively the inhibition of $\mathrm{Na}^{+}-\mathrm{K}^{+}-\mathrm{ATPase}$ activity observed after the administration of vinblastine. This could be partially explained on the basis of the histological changes observed in jejunum of rats treated with vinblastine or with methylprednisolone and vinblastine. In both groups significant changes were found in the superficial absorptive cells in addition to the mitotic arrest in metaphase observed in the colchicine treated rats.

This study demonstrated decreased absorptive capacity induced by colchicine and vinblastine without any evidence of increased secretion. The doses of colchicine, vinblastine, and methylprednisolone used in this study are also huge in comparison to the doses used for therapeutic purposes in humans. However, the fact that methylprednisolone was shown to prevent the effect of colchicine both on fluid transport and on Na-K-ATPase activity might be used to prevent diarrhoea in patients receiving colchicine or vinblastine for therapeutic purposes.

This work has been supported in part by a grant from the Joint Research Foundation of the Hebrew University and Hadassah University Hospital and by a grant from Mr Epstein to Dr D. Rachmilewitz.

\section{References}

Chajek, T., Stein, O., and Stein, Y. (1975). Colchicineinduced inhibition of plasma lipoprotein lipase release in the intact rat. Biochimica et Biophysica Acta, 380, 127-131.

Charney, A. N., and Donowitz, M. (1976). Prevention and reversal of cholera enterotoxin-induced intestinal secretion by methylprednisolone induction of $\mathrm{Na}^{+} \mathrm{K}+$ ATPase Journal of Clinical Investigation, 57, 1590-1599.

Charney, A. N., and Donowitz, M. (1977). Functional significance of intestinal Na-K-ATPase activity: in vivo ouabain inhibition of intestinal $\mathrm{Na}$ and water absorption (Abstract). Gastroenterology, 72, 1037.

Charney, A. N., Gots, R. E., and Gianella, R. A. (1974). $\left(\mathrm{Na}^{+} \mathrm{K}^{+}\right)$stimulated adenosinetriphosphatase in isolated intestinal villus tip and crypt cells. Biochimica et Biophysica Acta, 367, 265-270.

Charney, A. N., Kinsey, M. D., Myers, L., Giannella, R. A., and Gots, R. E. (1975). $\mathrm{Na}^{+} \mathrm{K}^{+}$activated adenosine triphosphatase and intestinal electrolyte transport. Journal of Clinical Investigation, 56, 653-660.

Cohen, M. I., and McNamara, H. (1970). Effect of colchicine on guinea pig intestinal enzyme activity. American Journal of Digestive Diseases, 15, 247-250.

Douglas, W. W., and Sorimachi, M. (1972). Colchicine inhibits adrenal medullary secretion evoked by acetylcholine without affecting that evoked by potassium. British Journal of Pharmacology, 45, 129-132.

Fiske, C. H., and SubbaRow, Y. (1925). The colorimetric determination of phosphorus. Journal of Biological Chemistry, 66, 375-400.

Herbst, J. J., Hurwitz, R., Sunshine, P., and Kretchmer, N. (1970). Effect of colchicine on intestinal disaccharidases: Correlation with biochemical aspects of cellular renewal. Journal of Clinical Investigation, 49, 530-536.

Lacy, P. E., Howell, S. L., Young, D. A., and Fink, C. J. (1968). New hypothesis of insulin secretion. Nature, 219, 1177-1179.

Lowry, O. H., Rosebrough, N. H., Farr, A. L., and Randall, R. J. (1951). Protein measurement with the Folin reagent. Journal of Biological Chemistry, 193, 265-275.

Myren, J., Luketic, G. C., Ceballos, R., Sachs, G., and 
Hurschowitz, B. I. (1966). Effects of colchicine on intestinal mucosal dehydrogenases. I. Histochemical observations. American Journal of Digestive Diseases, 11, 394-403.

Olmstead, J. B., and Borisy, G. G. (1973). Colchicine and vinblastine-two microtubular disrupting agents. Annual Review of Biochemistry, 42, 507-540.

Parsons, D. S., and Volman-Mitchell, H. (1974). The transamination of glutamate and aspartate during absorption in vitro by small intestine of chicken, guinea pig and rat. Journal of Physiology, 239, 677-694.

Quigley, J. P., and Gotterer, G. S. (1969). Distribution of $\left(\mathrm{Na}^{+} \mathrm{K}^{+}\right)$stimulated ATPase activity in rat intestinal mucosa. Biochimica et Biophysica Acta, 173, 456-468.

Rossignol, B., Herman, G., and Keryer, G. (1972). Inhibition by colchicine of carbamylcholine induced glycoprotein secretion by the submaxillary gland. A possible mechanism of cholinergic induced protein secretion. FEBS Letters, 21, 189-194.

Stadler, J., and Franke, W. W. (1974). Characterization of the colchicine binding of membrane fractions from rat and mouse liver. Journal of Cell Biology, 60, 297-303.

Williams, J. A., and Wolff, J. (1970). Possible role of microtubules in thyroid secretion. Proceedings of the National Academy of Sciences of the USA, 67, 1901-1908.

Zemer, D., Revach, M., Pras, M., Modan, B., Schor, S., Sohar, E., and Gafni, J. (1974). A controlled trial of colchicine in preventing attacks of familial Mediterranean fever. New England Journal of Medicine, 291, 932-934.

\section{The July 1978 Issue}

\section{THE JULY 1978 ISSUE CONTAINS THE FOLLOWING PAPERS}

Sialic acids of human large bowel mucosa:0-acylated variants in normal and malignant states C. $M$. ROGERS, K. B. COOKE, AND M. I. FILIPE

Quantitative comparison of the effects of cholecystokinin, secretin, and pentagastrin on gastrointestinal myoelectric activity in the conscious fasted dog D. L. WINGATE, E. A. PEARCE, M. HUTTON, A. DAND, H. H. THOMPSON, AND E. WÜNSCH

Alterations of the colonic flora and their effect on the hydrogen breath test T. GILAT, H. BEN HUR, E. GELMAN-MALACHI, R. TERDIMAN, AND Y. PELED

Low dose steroids and clinical relapse in Crohn's disease: a controlled trial R. C. SMITH, J. RHODES, R. V. HEATLEY, L. E. HUGHES, D. L. CROSBY, B. I. REES, H. JONES, K. T. EVANS, AND B. W. LAWRIE

Circulating immune complexes and disease activity in Crohn's disease R. FIASSE, A. Z. LURHUMA, C. L. CAMBIASO, P. L. MASSON, AND C. DIVE

Immune status in Crohn's disease. 2. Originally unimpaired primary cell mediated immunity in vitro I. O. AUER, CH. BUSCHMANN, AND E. ZIEMER

Alpha heavy chain disease (report of 18 cases from Iraq) z. AL-BAHRANI, T. AL-SALEEM, H. AL-MONDHIRY, F. BAKIR, H. YAHIA, I. TAHA, AND J. KING

Role of neural influences in the release of gastrins, glucagon, and secretin during hypoglycaemia in man J. C. MCLOUHLIN, J. R. HAYES, K. D. BUCHANAN, AND J. G. KELLY
Enterohepatic circulation of bile acids after cholecystectomy E. RODA, RITA ALDINI, G. MAZZELLA, A. RODA, CLAUDIA SAMA, D. FESTI, AND L. BARBARA

Changes in the electrolyte content of leucocytes at different clinical stages of cirrhosis A. N. ALAM, P. WHEELER, S. P. WILKINSON, L. POSTON, C. GOLINDANO, AND ROGER WILLIAMS

Gastrointestinal somatostatin: extraction and radioimmunoassay in different species C. McINTOSH, R. ARNOLD, E. BOTHE, H. BECKER, J. KÖBBERLING, AND W. CREUTZFELDT

Twenty-four hour gastric acidity after vagotomy R. F. MCCLOY, D. P. GIRVAN, AND J. H. BARON

Tube introducer and modified Celestin tube for use in palliative intubation of oesophagogastric neoplasms at fibreoptic endoscopy M. ATKINSON, R. FERGUSON, AND G. C. PARKER

Value of laparoscopy in the diagnosis and management of pancreatic carcinoma A. CUSCHIERI, A. W. HALL, AND JOHN CLARK

Notes and activities

Books

Copies are still available and may be obtained from the PUBLISHING MANAGER, BRITISH MEDICAL ASSOCIATION, TAVISTOCK SQUARE, LONDON WC1H 9JR, price $£ 2 \cdot 75$, including postage 